CLINICAL STUDY

\title{
Effects of anabolic-androgenic steroid use or gonadal testosterone suppression on serum leptin concentration in men
}

\author{
M S Hislop, B D Ratanjee, S G Soule and A D Marais \\ Lipid Laboratory, Department of Internal Medicine, University of Cape Town Medical School, Anzio Road, Observatory, 7925, South Africa \\ (Correspondence should be addressed to A D Marais, Lipid Laboratory, 5th Floor SAMIOT Building, University of Cape Town Medical School, \\ Observatory 7925, South Africa)
}

\begin{abstract}
Objective: Serum leptin concentration shows a sexual dimorphism that is not accounted for by gender differences in adiposity. A strong inverse association exists between serum leptin and testosterone concentrations in men, pointing to a likely influence of gonadal sex steroids on serum leptin concentration. The aim of this study was to investigate whether manipulation of sex steroid hormones in men would alter serum leptin concentration independently of changes in fat mass.

Design and methods: The effects of sex steroid suppression on serum leptin concentration were investigated in nine healthy men in whom testosterone had been reversibly suppressed for 5 weeks after treatment with intramuscular triptorelin. The effects of sex steroid supplementation were investigated in nine male bodybuilders who self-administered anabolic-androgenic steroids (AAS) for a mean period of 6.5 weeks. A control group received no hormonal treatment.

Results: Testosterone concentration was significantly reduced by triptorelin administration $(7.32 \pm$ $1.92 \mathrm{ng} / \mathrm{ml}$ at baseline compared with $1.15 \pm 0.57 \mathrm{ng} / \mathrm{ml}$ at 5 weeks, $P=0.002$ ). High-dose AAS use was confirmed by urine analysis. Body fat percentage was unaffected by the AAS or triptorelin intervention $(P>0.19)$. Leptin concentration was significantly reduced after one cycle of AAS use $(2.40 \pm 0.98 \mathrm{ng} / \mathrm{ml}$ off cycle compared with $1.63 \pm 0.37 \mathrm{ng} / \mathrm{ml}$ on cycle, $P=0.012)$, and was significantly increased by triptorelin administration $(2.96 \pm 1.50 \mathrm{ng} / \mathrm{ml}$ at baseline compared with $6.63 \pm 4.67 \mathrm{ng} / \mathrm{ml}$ at five weeks, $P=0.004)$. No significant change occurred in the control group.

Conclusion: Androgenic sex hormone supplementation decreases serum leptin concentration, whereas suppression increases serum leptin concentration, independently of changes in body fat mass in healthy men. The sexual dimorphism evident in serum leptin concentration is likely to be due to a suppressive effect of testosterone on serum leptin concentration in males.
\end{abstract}

European Journal of Endocrinology 141 40-46

\section{Introduction}

Leptin is a 167-amino acid product of the $o b$ gene, produced mainly in adipose tissue $(1,2)$. In rodents, leptin appears to have a role as an adipocyte-derived signalling molecule that regulates food intake and energy expenditure. Leptin-deficient $(o b / o b)$ or resistant $(d b / d b)$ rodents thus exhibit hyperphagia and reduced metabolic rate, with consequent massive obesity $(3,4)$. These abnormalities are reversed by administration of leptin in the $o b / o b$ mouse (4). The role of leptin in the pathophysiology of human obesity is less clear than it appears to be in rodent models of obesity (5). Serum leptin concentrations are closely correlated with body fat percentage in humans. The high leptin concentrations that characterise most obese people are suggestive of a deficiency in the feedback loop between leptin, appetite and energy expenditure. Leptin deficiency, resulting from a mutation in the leptin gene, and resistance, resulting from a mutation in the leptin receptor, have been defined in humans, although they appear to be rare events $(6,7)$.

Besides its metabolic role, leptin may also be closely associated with reproduction and neuroendocrine signalling. Notably, the infertility characteristic of female $o b / o b$ mice is corrected by treatment with human recombinant leptin (8). Moreover, leptin appears to trigger the onset of puberty (9) and reproductive function (10) in normal female rodents. In humans, serum leptin increases before the onset of 
puberty in both sexes (11), suggesting that a critical concentration of leptin may be a permissive factor for the initiation of puberty (12). After Tanner stage 2, serum leptin concentrations diverge in males compared with females, even if body fat percentage is taken into account (11). Accordingly, the possibility exists that leptin concentrations may, in turn, be influenced by gonadal sex steroid hormones. This hypothesis has gained credence through a number of recent studies. First, cross-sectional analyses have defined a negative correlation between testosterone and leptin in both boys (13) and adult men (14-17). Secondly, in vitro studies using human adipocytes in culture show that testosterone suppresses leptin mRNA synthesis and leptin secretion (13). Thirdly, increased serum leptin concentration in hypogonadal men is normalised by testosterone substitution (18), and suppression of testosterone in boys is associated with a reduction in serum leptin concentration (19). Finally, manipulation of the hormone milieu in transsexuals reverses the gender disparity in serum leptin concentration (20). In this study, we examined the effect of both an acute increase and an acute decrease in sex steroid hormones on serum leptin concentration in healthy men.

\section{Subjects and methods}

\section{Subjects and anthropometry}

The effect of androgen supplementation on plasma leptin concentration was investigated in male bodybuilders who self-obtained and self-administered anabolic-androgenic steroids (AAS) on a cyclical basis. The study was advertised locally, and nine male bodybuilders (age 21-27 years, mean 25 2 years) volunteered to participate. Subjects typically trained four to six times a week, with training sessions comprising $1-1.5 \mathrm{~h}$ of heavy resistance training and $30 \mathrm{~min}$ of 'aerobic' training. Ethical considerations precluded the investigators from advising subjects on cycle durations and AAS dosage. Accordingly, test interventions occurred at the convenience of the participants, at the end of one 'on' cycle (using AAS) and one 'off' cycle (not using AAS). Subjects used a variety of oral and parenteral AAS, in a cyclical fashion, typically spending 6-10 weeks on cycle, followed by 4-8 weeks off cycle. Subjects used, on average, $990 \mathrm{mg} 17 \beta$-esterified and $375 \mathrm{mg} 17 \alpha$ alkylated AAS per week for an average 6.5 weeks. They agreed to use no AAS during their off cycle. To confirm AAS usage, urine analysis was performed at the end of both on and off cycles, at a control laboratory accredited by the International Olympic Committee (IOC). Subjects acted as their own controls. The effect of androgen suppression on plasma leptin concentration was investigated in healthy men, in whom testosterone production had been reversibly suppressed using the gonadotropin-releasing hormone
$(\mathrm{GnRH})$ agonist, triptorelin (Decapeptyl; D-Trp ${ }^{6}$ luteinising hormone-releasing hormone). These men were participants in an open, randomised, crossover trial, designed to compare the efficacy and tolerance of two triptorelin sustained-release formulations. The trial comprised two parts, the second of which followed 3 months after the commencement of the first, once testosterone concentrations had been within the normal concentration range for several weeks. The study group comprised nine healthy male volunteers (age 23-55 years, mean $31 \pm 10$ years). Relevant variables were compared during the second part of the crossover, both before triptorelin administration and five weeks after drug administration. The latter time point was established as the nadir of serum testosterone concentration in the first part of the study. A group comprising eight healthy men with normal testosterone concentrations were assessed in parallel with the trial group to provide analytical control. They were matched with the trial group on the basis of age (28 \pm 11 years), socioeconomic status and relative physical activity.

The study was approved by the Ethics and Research Committee of the University of Cape Town. Subjects were fully informed about the relevant procedure, and gave written informed consent before commencement of the study. All were healthy as judged by medical history, physical examination, and liver function tests. They were requested not to modify any of their lifestyle habits, exercise regimens or diet, through the duration of the studies. Height was measured to $0.1 \mathrm{~cm}$, and body mass to $0.1 \mathrm{~kg}$. Anthropometry was performed by an individual experienced in anthropometric measurement, using standardised anthropometric landmarks to locate the measuring sites (21). Body fat percentage and muscle mass were calculated as described elsewhere $(22,23)$.

\section{Biochemical analyses}

Blood samples were collected between 0700 and $0730 \mathrm{~h}$, after an overnight fast, and stored at $-20^{\circ} \mathrm{C}$. Plasma leptin concentrations were measured in duplicate by an RIA (Linco Research, Inc., St Louis, MO, USA) (24). The intra-assay coefficient of variation was $1.4 \%$. Serum testosterone concentrations were measured in duplicate by means of a specific RIA performed on extracts of the plasma samples, using an in-house antiserum and tritiated testosterone label as the tracer. Inter- and intra-assay coefficients of variation were $11.6 \%$ and $4.6 \%$ respectively. Insulin concentrations were measured using a solid-phase iodine-125 RIA (Coat-A-Count Insulin, Diagnostic Products Corporation, Los Angeles, CA, USA). AAS were detected by gas chromatography with a mass-selective detector after deconjugation and derivatisation of the urine extracts (25). Total and high-density lipoprotein cholesterol (HDLC) concentrations were evaluated using 
commercially available enzymatic spectrophotometric kits.

\section{Statistics}

A statistical software package (Instat, Graphpad Software, Inc. San Diego, CA, USA) was used for data analysis. Data are expressed as a mean \pm s.D. Data were analysed using non-parametric methods, with the Wilcoxon matched pairs test. Correlation (non-parametric, Spearman) and linear regression were assessed using another software package (Graphpad Prism). A value of $P<0.05$ was accepted to define statistical significance.

\section{Results}

\section{Anthropometry}

Body mass of the AAS users had increased significantly by the end of the on cycle, from $96.2 \pm 11.1 \mathrm{~kg}$ to $99.7 \pm 11.1 \mathrm{~kg}(P=0.004)$. Muscle mass increased from $60.8 \pm 7.6$ to $62.5 \pm 7.5 \mathrm{~kg}(P=0.03)$. There was no change in fat percentage on cycle $(13.5 \pm 3.5 \%$ compared with $13.0 \pm 2.8 \%, P=0.36$ ). Body mass $(80.8 \pm 12.2 \mathrm{~kg}$ and $81.4 \pm 12.7 \mathrm{~kg}, P=0.65)$, muscle mass $(43.3 \pm 6.1 \mathrm{~kg}$ and $43.5 \pm 6.2 \mathrm{~kg}, P=0.91)$ and fat percentage $(20.1 \pm 6.8 \%$ and $19.9 \pm 7.1 \%, P=0.20)$ did not change between tests 1 and 2 in the triptorelintreated group. Likewise, body mass $(76.1 \pm 10.7 \mathrm{~kg}$ and $76.3 \pm 11.6 \mathrm{~kg}, P=0.69)$, muscle mass $(42.0 \pm 6.0 \mathrm{~kg}$ and $41.8 \pm 5.7 \mathrm{~kg}, P=0.47)$ and fat percentage $(16.7 \pm$ $7.7 \%$ and $16.3 \pm 8.4 \%, P=0.69)$ did not change between tests 1 and 2 in the control group.

\section{Anabolic-androgenic steroids}

AAS use was confirmed in all nine of the bodybuilders, by urine analysis. During the on cycle, testosterone esters were detected in all of them, and nandrolone was detected in eight. Low concentrations of nandrolone could be detected in seven of the subjects, at the end of their off cycle 'washout period'; these were, most probably, remnants of the previous cycle. In one of the group, testosterone and stanozolol from a previous cycle could be detected during his 'washout period'. Subsequent to the on cycle period, one bodybuilder admitted supplementing his AAS use with growth hormone (GH) i.m. $25 \mathrm{IU} /$ week for 7 weeks. The other men denied use of $\mathrm{GH}$.

\section{Lipoproteins}

In the AAS users, mean HDLC concentration decreased significantly when subjects were on cycle, from $0.9 \pm$ $0.3 \mathrm{mmol} / \mathrm{l}$ to $0.7 \pm 0.3 \mathrm{mmol} / \mathrm{l} \quad(P=0.004)$. Mean total cholesterol $(5.40 \pm 1.99 \mathrm{mmol} / \mathrm{l}$ compared with
$4.83 \pm 1.17 \mathrm{mmol} / \mathrm{l}, P>0.3)$ and low-density lipoprotein cholesterol $(3.97 \pm 1.97 \mathrm{mmol} / \mathrm{l}$ compared with $3.66 \pm 1.27 \mathrm{mmol} / \mathrm{l}, P>0.5$ ) were unchanged on cycle. Fasting triglyceride concentrations were unchanged between the off and on cycles $(1.1 \pm 0.5 \mathrm{mmol} / \mathrm{l} \mathrm{com-}$ pared with $1.0 \pm 0.3 \mathrm{mmol} / \mathrm{l}, P=0.73)$.

Mean total cholesterol increased after 5 weeks in the triptorelin group $(4.8 \pm 0.8 \mathrm{mmol} / \mathrm{l}$ compared with $5.2 \pm 1.0 \mathrm{mmol} / \mathrm{l}, P=0.04)$, and did not change in the control group $(4.9 \pm 1.1 \mathrm{mmol} / \mathrm{l}$ compared with $4.9 \pm$ $0.9 \mathrm{mmol} / \mathrm{l}, \quad P>0.94)$. Mean HDLC concentration increased significantly after 5 weeks in the triptorelin group (from $1.1 \pm 0.2 \mathrm{mmol} / \mathrm{l}$ to $1.4 \pm 0.3 \mathrm{mmol} / \mathrm{l}$, $P=0.002)$; it did not change in the control group $(1.2 \pm 0.2 \mathrm{mmol} / \mathrm{l}$ compared with $1.2 \pm 0.1 \mathrm{mmol} / \mathrm{l})$. Fasting triglyceride concentrations were unchanged between the two test dates in both the triptorelin $(1.2 \pm 0.2 \mathrm{mmol} / \mathrm{l}$ compared with $1.3 \pm 0.7 \mathrm{mmol} / \mathrm{l}$, $P=0.63)$ and control groups $(1.0 \pm 0.5 \mathrm{mmol} / \mathrm{l} \mathrm{com}-$ pared with $1.0 \pm 0.4 \mathrm{mmol} / \mathrm{l}, P=0.47$ ).

\section{Testosterone and insulin}

Plasma testosterone concentration was not measured in the AAS group. Baseline testosterone concentration in the triptorelin group $(7.32 \pm 1.92 \mathrm{ng} / \mathrm{ml})$ was similar to that in the control group $(7.30 \pm$ $2.08 \mathrm{ng} / \mathrm{ml}$; normal range $3-10 \mathrm{ng} / \mathrm{ml})(26)$. Testosterone concentration was significantly reduced with triptorelin therapy, to $1.15 \pm 0.57 \mathrm{ng} / \mathrm{ml}$ after 5 weeks $(P=0.002)$, but did not change in the control group $(6.50 \pm 2.18 \mathrm{ng} / \mathrm{ml}$ at 5 weeks, $P>0.38)$. A plot of testosterone concentration against time in the triptorelin group (Fig. 1), shows that test 2, performed 5.35.8 weeks after triptorelin was administered, coincided with the nadir of testosterone concentration.

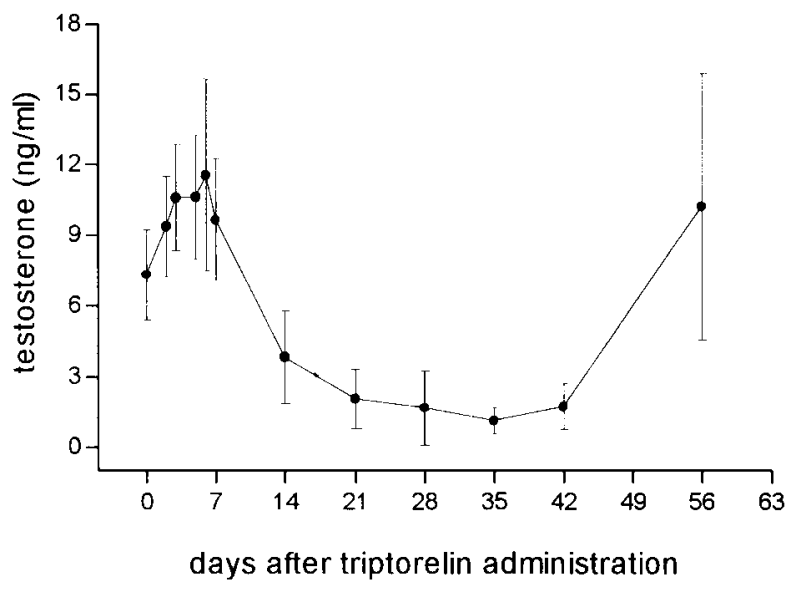

Figure 1 Effect of triptorelin on testosterone concentration in nine healthy men (mean \pm S.D.). Leptin concentrations were measured at day 0 and day 35 (5 weeks) after triptorelin administration, when testosterone concentrations were at their nadir. 
Insulin concentration was unchanged after one cycle of AAS use $(5.22 \pm 1.69 \mu \mathrm{U} / \mathrm{ml}$ off cycle compared with $4.86 \pm 1.67 \mu \mathrm{U} / \mathrm{ml}$ on cycle, $P>0.24$ ), and was unchanged 5 weeks after administration of triptorelin in the experimental $(7.34 \pm 7.05 \mu \mathrm{U} / \mathrm{ml}$ at baseline and $7.10 \pm 4.28 \mu \mathrm{U} / \mathrm{ml}$ at 5 weeks, $P>0.70)$ and control groups $(3.71 \pm 1.43 \mu \mathrm{U} / \mathrm{ml}$ at baseline and $5.15 \pm$ $3.79 \mu \mathrm{U} / \mathrm{ml}$ at 5 weeks, $P>0.58)$.

\section{Leptin}

Leptin concentration was significantly increased by triptorelin administration $(2.96 \pm 1.50 \mathrm{ng} / \mathrm{ml}$ at baseline and $6.63 \pm 4.67 \mathrm{ng} / \mathrm{ml}$ at 5 weeks, $P=0.004$; Fig. 2), did not change in the control group (2.31 \pm $1.12 \mathrm{ng} / \mathrm{ml}$ at baseline and $2.94 \pm 1.89 \mathrm{ng} / \mathrm{ml}$ at 5 weeks, $P>0.46$ ), and was significantly reduced after one cycle of AAS use $(2.40 \pm 0.98 \mathrm{ng} / \mathrm{ml}$ off cycle compared with $1.63 \pm 0.37 \mathrm{ng} / \mathrm{ml}$ on cycle, $P=0.012$; Fig. 3).

There was a significant correlation between fat percentage and leptin for all participants before intervention $\left(P<0.001, n=24, y=0.14 x+0.35, \mathrm{r}^{2}=0.53\right.$, $95 \%$ confidence interval (CI) of slope 0.09 to 0.20 ). The association between fat percentage and leptin was significantly strengthened after the suppression of testosterone in the triptorelin group (before intervention: $n=8, \mathrm{r}^{2}=0.87, P=0.002 ; y=0.21 x-0.92$, 95\% CI 0.11 to 0.31 ; after intervention: $n=8$, $\mathrm{r}^{2}=0.90, P=0.001 ; y=0.66 x-5.71,95 \%$ CI 0.39 to 0.93). The association between fat percentage and leptin was unchanged after one cycle of AAS use, and in the control group. When the percentage change in leptin concentration in response to triptorelin was analysed as a function of the baseline concentration, linear regression indicated that the baseline concentration explained $59 \%$ of the variance, with $P<0.02$.

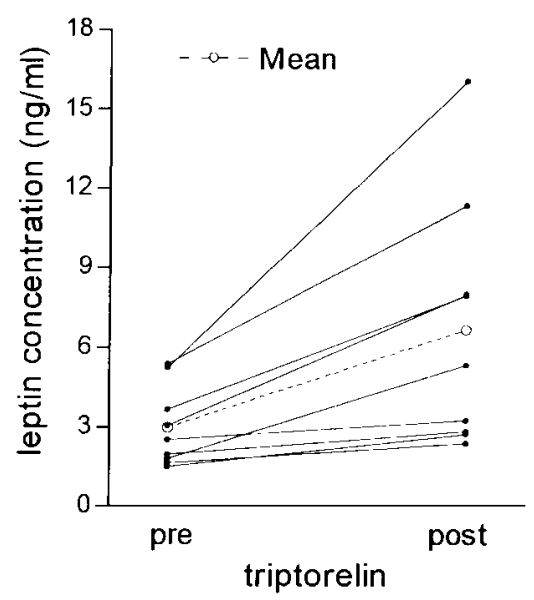

Figure 2 Plasma leptin concentration before and 5 weeks after triptorelin treatment in nine healthy men.

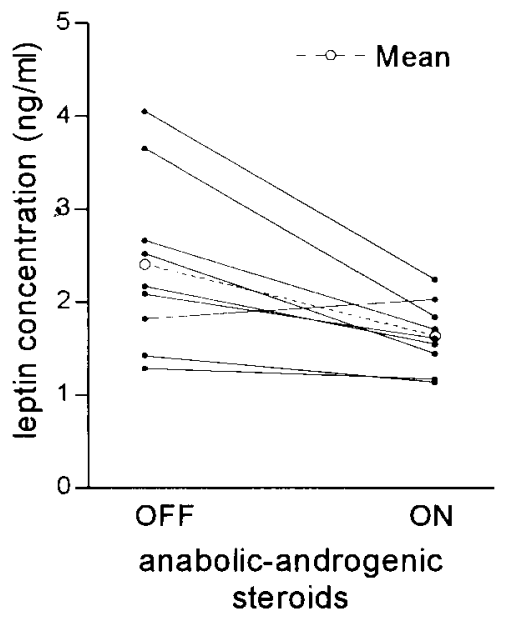

Figure 3 Plasma leptin concentration before and after one cycle (mean 6.5 weeks) of AAS self-administration in nine male bodybuilders.

\section{Discussion}

This study shows that manipulation of the sex steroid hormones in normal healthy men causes significant changes in serum leptin concentration, independently of changes in body fat mass or insulin concentration. Specifically, we show that sex hormone supplementation, with high doses of AAS, causes a significant reduction in serum leptin concentration, whereas sex hormone suppression causes a significant increase in serum leptin concentration in adult men. It is notable that the suppression of sex steroid hormones significantly enhances the strength of the correlation between body fat percentage and serum leptin concentration in men.

Investigation of the effects of AAS on serum leptin concentration was complicated by ethical considerations that precluded investigator involvement in drug administration. To be sure that subjects had selfadministered AAS, urine samples collected at the end of the on and off cycle periods were sent for urine analysis at an IOC-accredited laboratory. These tests showed that all subjects had used AAS during the on cycle period. Residual concentrations were also detectable at the end of the washout period, in seven of the nine bodybuilders, indicating that traces of AAS remained from the previous cycle (data not shown). It is likely that the change in leptin concentration between the on and off cycle periods would have been greater than that observed had the individuals been entirely free of AAS during the off cycle period. Additional proof for AAS usage was provided by the change in HDLC concentration, which is very sensitive to the presence of AAS (27). In the bodybuilders we studied, HDLC concentration showed the anticipated marked decline during the on cycle period, and increase during the off cycle period. We are thus confident that the 
self-administration of AAS was consistent with that reported by our subjects.

To our knowledge, a reduction in serum leptin concentration as a result of AAS use in healthy men has not previously been described. This result is consistent with the finding that testosterone substitution reduces serum leptin concentration in hypogonadal males (18). AAS use appears to have a similar suppressive effect on serum leptin concentration in females (unpublished data) - an observation in keeping with the finding that testosterone enanthate substitution suppresses serum leptin concentration in female-to-male transexuals (20). By comparison, and in view of the first finding, the increase in serum leptin concentration after endogenous testosterone suppression would be anticipated. This result is consistent with reports that serum leptin concentration is suppressed in male-to-female transexuals receiving cyproterone acetate (antiandrogen) and ethinyl oestradiol therapy (20), and in boys treated with a GnRH agonist for central precocious puberty (19).

Because body fat mass is a strong determinant of serum leptin concentration in humans $(28,29)$, and because gonadal steroids influence body fat mass and distribution, an important consideration in studies of this kind is whether changes in serum leptin concentration are the result of changes in sex steroid concentration per se, or of changes in body fat mass in the period between leptin measurements. Gonadal sex hormone supplementation appears to have minimal effect on body fat mass in men with testosterone concentration in the normal range (30). This treatment does, however, tend to increase lean body mass $(30,31)$ which can result in a reduction in body fat expressed as a percentage. In the present study, no change in body fat mass could be detected, and there was only a very slight and non-significant decrease in body fat percentage during AAS use. It has been demonstrated that non-visceral adipose tissue influences leptin concentration more than does visceral adipose tissue $(32,33)$. The lean, active young men included in this study had relatively little total fat and thus also little visceral fat. Furthermore, in the short course of the study, neither visceral nor non-visceral fat is likely to change appreciably. Given the magnitude of the decrease in serum leptin concentration with AAS use, the small changes in body fat percentage are unlikely to account for the significant reduction in serum leptin concentration seen in these men.

The possibility that sex steroid supplementation might influence serum leptin concentration, through its effect on body fat mass, is of greater concern in studies on hypogonadal males. Sex steroid supplementation has a more pronounced effect on body fat mass in these individuals, possibly because they tend to have a body fat percentage that is greater than that in eugonadal males (34). These changes do, however, only appear to become evident after a number of months of steroid treatment. Investigators report no changes in body fat mass after 2-3 (35) and 6 months of testosterone supplementation (36), and significant reductions only after 6 (37) to 18 months (34) of testosterone supplementation. We are aware of only one study that has investigated the effect of sex steroid supplementation on serum leptin concentration in hypogonadal males (18). Although percentage body fat was not reported in that study, body mass index showed no decrease after 100 days of testosterone replacement therapy. This finding is consistent with the reports showing no reduction in body fat percentage within 6 months of starting testosterone replacement therapy in hypogonadal males $(35,36)$, supporting the contention that the effects of testosterone supplementation on serum leptin are independent of changes in body fat mass.

Gonadal steroid suppression can also lead to marked changes in body fat percentage in healthy males. In the study reported by Elbers et al. (20), body fat mass increased significantly in male-to-female transexuals in the period between serum leptin measurements. It was, however, possible to show, by analysis of covariance, that changes in serum leptin concentration were independent of changes of body fatness in this group, indicating that changes in serum leptin concentration were likely to be determined by sex steroid hormones rather than changes in body fat composition. Similarly, Palmert et al. (19) did not report body fat mass, and commented that the possibility could not be excluded that changes in body composition had occurred over the 6-month period of their study. Nonetheless, they found only small differences among the body mass indexes of boys across the time-points of the paired analysis, indicating that changes in serum leptin concentration were unlikely to be accounted for by changes in body fat composition. In our study, no changes in body fat percentage could be detected during the relatively short duration of the study. This finding confirms the previous conclusions that changes in serum leptin concentration are mainly due to changes in testosterone concentration, rather than to changes in body fat percentage.

A number of other endocrine factors may also have influenced serum leptin concentrations in our study. Prolonged exposure of adipocytes to insulin appears to increase leptin secretion (38). In the present study, fasting insulin concentration did not change with either triptorelin therapy or anabolic steroid use, which argues against this hypothesis. Furthermore, GH replacement results in a decrease in serum leptin (39). Accordingly, one cannot exclude the possibility that covert GH administration in some of the AAS users may have played a part in the fluctuations in serum leptin; however, interviews with these men indicated that this was unlikely in all but one of them.

It is notable that the percentage change in serum leptin concentration with sex steroid manipulation 
differed between individuals in the present study. There was no correlation between the initial or percentage change in testosterone concentration and the percentage change in serum leptin concentration in the triptorelin group. There was, however, a correlation between the initial leptin concentration and the percentage change in leptin concentration following androgen manipulation in both the triptorelin and AAS groups. Although it was our impression that persons with more body fat had higher initial concentrations of leptin, the group was too small to analyse further the determinants of leptin concentration and its change.

All participants were asked to keep dietary records for analysis during the study. Dietary records taken in the AAS group indicated a strict commitment in each individual to a selected putative anabolic diet that contained little fat $(20 \%)$. The dietary records from the triptorelin group indicated that the group had a more traditional western style diet (about $50 \%$ as fat). None of the participants reported a change in appetite and no change in eating habits was reflected in the records. This raises the question of whether serum leptin concentration has any relevance in the control of appetite in man in the short term, although it may have in the longer term (40).

The powerful suppressive effect of gonadal sex steroids on serum leptin concentration observed in these studies lends support to the hypothesis that male sex hormones are the main cause of the sexual dimorphism in serum leptin concentration (41-43). This finding is also consistent with the observation that there is a strong negative correlation between serum leptin concentration and testosterone concentration in men (14-16). The fact that leptin concentration changed without a concomitant measureable change in adipose mass supports an independent effect of testosterone on serum leptin concentration in vivo; the mechanism for such an effect in vivo is unknown at present. The change is likely to be due to a suppressive effect of gonadal sex steroids on leptin mRNA, thereby reducing leptin secretion from adipose tissue, as has been found in vitro (13), or possibly to alterations in the metabolic clearance of leptin, mediated perhaps by changes in binding proteins.

In conclusion, our studies have confirmed and extended the observation of a direct modulatory effect of androgenic steroids on serum leptin concentration in vivo. By studying the effects of exogenous androgen supplementation and the impact of GnRH agonistinduced hypogonadism on leptin concentrations in normal men, we confirm the effect of androgen supplementation on reducing serum leptin and demonstrate that suppression of physiological concentrations of serum testosterone results in a marked increase in serum leptin concentration in normal men, independently of changes in body fat mass.

\section{Acknowledgements}

We would like to express our gratitude to Dr Alan St Clair Gibson for his assistance with recruitment of participants and sample collection, Dr Mike Lambert for performing all anthropometric measurements, and Professor Tim Noakes for providing facilities for testing the participants.

This study formed part of investigations by the Medical Research Council Heart Group.

\section{References}

1 Zhang Y, Proenca R, Maffei M, Barone M, Leopold L \& Friedman JM. Positional cloning of the mouse obese gene and its human homologue. Nature 1994372 425-432.

2 Halaas JL, Gajiwala KS, Maffei M, Cohen SL, Chait BT, Rabinowitz $\mathrm{D}$ et al. Weight-reducing effects of the plasma protein encoded by the obese gene. Science 1995269 543-546.

3 Pelleymounter M, Cullen MJ, Baker MB, Hecht R, Winters D, Boone $\mathrm{T}$ et al. Effects of the obese gene product on body weight regulation in ob/ob mice. Science 1995269 540-563.

4 Lee GH, Proenca R, Montez JM, Carroll KM, Darvishzadeh JG, Lee JI et al. Abnormal splicing of the leptin receptor in diabetic mice. Nature $1996379632-635$.

5 Auwerx J \& Staels B. Leptin. Lancet 1998351 737-742.

6 Montague CT, Farooqi IS, Whitehead JP, Soos MA, Rau H, Wareham NJ et al. Congenital leptin deficiency is associated with severe early-onset obesity in humans. Nature 1997387 903-907.

7 Clement K, Vaisse C, Lahlou N, Cabrol S, Pelloux V, Cassuto D et al. A mutation in the human leptin receptor gene causes obesity and pituitary dysfunction. Nature 1998392 398-401.

8 Chebab F, Lim M \& Lu R. Correction of the sterility defect in homozygous obese female mice by treatment with the human recombinant leptin. Nature Genetics 199612 318-320.

9 Chehab FF, Mounzih K, Lu R \& Lin ME. Early onset of reproductive function in normal female mice treated with leptin. Science 1997 $27588-90$.

10 Cheung CC, Thornton JE, Kuijper JL, Weigle DS, Clifton DK \& Steiner RA. Leptin is a metabolic gate for the onset of puberty in the female rat. Endocrinology 1997138 855-888.

11 Blum WF, Englaro P, Hanitsch S, Juul A, Hertel NT, Muller J et al. Plasma leptin levels in healthy children and adolescents: dependence on body mass index, body fat mass, gender, pubertal stage, and testosterone. Journal of Clinical Endocrinology and Metabolism 199782 2904-2910.

12 Garcia-Mayor R, Andrade MA, Rios M, Lage M, Dieguez C \& Casaneuva FF. Serum leptin levels in normal children: relationship to age, gender, body mass index, pituitary-gonadal hormones and pubertal stage. Journal of Clinical Endocrinology and Metabolism 199782 2849-2855.

13 Wabitsch M, Blum WF, Muche R, Braun M, Hube F, Rascher W et al. Contribution of androgens to the gender difference in leptin production in obese children and adolescents. Journal of Clinical Investigation $1997100808-813$.

14 Vettor R, De Pergola G, Pagano C, Englaro P, Laudadio E, Giorgino $\mathrm{F}$ et al. Gender differences in serum leptin in obese people: relationships with testosterone, body fat distribution and insulin sensitivity. European Journal of Clinical Investigation 1997 27 1016-1024.

15 Paolisso G, Rizzo MR, Mone CM, Tagliamonte MR, Gambardella A, Riondino et al. Plasma sex hormones are significantly associated with plasma leptin concentration in healthy subjects. Clinical Endocrinology 199848 291-297.

16 Behre HM, Simoni M \& Nieschlag E. Strong association between serum levels of leptin and testosterone in men. Clinical Endocrinology $199747237-240$. 
17 Nystrom F, Ekman B, Osterlund M, Lindstrom T, Ohman KP \& Arnqvist HJ. Serum leptin concentrations in a normal population and in GH deficiency: negative correlation with testosterone in men and effects of GH treatment. Clinical Endocrinology 199747 191-198.

18 Jockenhovel F, Blum WF, Vogel E, Englaro P, Muller-Wieland D, Reinwein D et al. Testosterone substitution normalizes elevated serum leptin levels in hypogonadal men. Journal of Clinical Endocrinology and Metabolism 199782 2510-2513.

19 Palmert MR, Radovick S \& Boepple PA. The impact of reversible gonadal sex steroid suppression on serum leptin concentrations in children with central precocious puberty. Journal of Clinical Endocrinology and Metabolism 199883 1091-1096.

20 Elbers JM, Asscheman H, Seidell JC, Frolich M, Meinders AE \& Gooren LJ. Reversal of the sex difference in serum leptin levels upon cross-sex hormone administration in transsexuals. Journa of Clinical Endocrinology and Metabolism 199782 3267-3270.

21 Ross WD \& Marfell-Jones MJ. Kinanthropometry. In Physiological Testing of the High-Performance Athlete, edn 2. Eds JD MacDougall, HA Wenger \& HJ Green. Champaign, IL, USA: Human Kinetics Books 1991.

22 Durnin JVGA \& Womersley J. Body fat assessed from the total body density and its estimation from skinfold thickness: measurements on 481 men and women aged from 16 to 72 years. British Journal of Nutrition 197432 77-97.

23 Martin AD, Spenst LF, Drinkwater DT \& Clarys JP. Anthropometric estimation of muscle mass in men. Medicine and Science in Sports and Exercise 199022 729-733.

24 Ma Z, Gingerich RL, Santiago JV, Klein S, Smith CH \& Landt M. Radioimmunoassay of leptin in human plasma. Clinical Chemistry $199642942-946$.

25 van der Merwe PJ \& Kruger HSL. Drugs in sport - results of the past 6 years of dope testing in South Africa. South African Medical Journal 199282 151-153.

26 Fauci AS, Braunwald E, Isselbacher KJ, Wilson JD, Martin JB, Kasper DL et al. (eds). Harrison's Principles of Internal Medicine, edn 14, p 2040. New York, USA: McGraw-Hill, 1998.

27 Glazer G. Atherogenic effects of anabolic steroids on serum lipid levels. Archives of Internal Medicine 1991151 1925-1933.

28 Considine RV, Sinha MK, Heiman ML, Kriauciunas A, Stephens TW, Nyce MR et al. Serum immunoreactive leptin concentrations in normal weight and obese humans. New England Journal of Medicine 1996334 292-295.

29 Maffei M, Halaas J, Ravussin E, Pratley RE, Lee GH, Zhang Y et al. Leptin levels in human and rodent: measurement of plasma leptin and ob RNA in obese and weight-reduced subjects. Nature Medicine 19951 1155-1161.

30 Kuipers H, Wijnen JAG, Hartgens F \& Willems SMM. Influence of anabolic steroids on body composition, blood pressure, lipid profile and liver functions in body builders. International Journal of Sports Medicine 199112 413-418.

31 Bhasin S, Storer TW, Berman N, Callegari C, Clevenger B, Phillips J et al. The effects of supraphysiologic doses of testosterone on muscle size and strength in normal men. New England Journal of Medicine $19963351-7$.

32 Hube F, Lietz U, Igel M, Jensen PB, Tornqvist H, Joost HG et al. Difference in leptin mRNA levels between omental and subcutaneous abdominal adipose tissue from obese humans. Hormone and Metabolic Research 199628 690-693.

33 Montague CT, Prins JB, Sanders L, Digby JE \& O’Rahilly S. Depotand sex-specific differences in human leptin mRNA expression: implications for the control of regional fat distribution. Diabetes $199746342-347$.

34 Katznelson L, Finkelstein JS, Schoenfeld DA, Rosenthal DI, Anderson EJ \& Klibanski A. Increase in bone density and lean body mass during testosterone administration in men with acquired hypogonadism. Journal of Clinical Endocrinology and Metabolism 199681 4358-4365.

35 Morley JE, Perry HM III, Kaiser FE, Kraenzle D, Jensen J, Houston K et al. Effects of testosterone replacement therapy in old hypogonadal males: a preliminary study. Journal of the American Geriatric Society 199341 149-152.

36 Wang C, Eyre DR, Clark R, Kleinberg D, Newman C. Iranmanesh A et al. Sublingual testosterone replacement improves muscle mass and strength, decreases bone resorption, and increases bone formation markers in hypogonadal men - a clinical research center study. Journal of Clinical Endocrinology and Metabolism 1996 $813654-3662$.

37 Brodsky IG, Balagopal P \& Nair KS. Effects of testosterone replacement on muscle mass and muscle protein synthesis in hypogonadal men - a clinical research center study. Journal of Clinical Endocrinology and Metabolism 199681 34693475 .

38 Kolaczynski JW, Nyce MR, Considine RV, Boden G, Nolan JJ, Henry $\mathrm{R}$ et al. Acute and chronic effects of insulin on leptin production in humans: studies in vivo and in vitro. Diabetes 1996 45 699-701.

39 Florkowski CM, Collier GR, Zimmet PZ, Livesey JH, Espiner EA \& Donald RA. Low-dose growth hormone replacement lowers plasma leptin and fat stores without affecting body mass index in adults with growth hormone deficiency. Clinical Endocrinology $199645769-773$.

40 Ravussin E, Pratley RE, Maffei M, Wang H, Friedman JM, Bennett $\mathrm{PH}$ et al. Relatively low plasma leptin concentrations precede weight gain in Pima Indians. Nature Medicine 19973 238-240.

41 Saad MF, Damani S, Gingerich RL, Riad-Gabriel MG, Khan A, Boyadjian R et al. Sexual dimorphism in plasma leptin concentration. Journal of Clinical Endocrinology and Metabolism 199782 579-584.

42 Rosenbaum M, Nicolson M, Hirsch J, Heymsfield SB, Gallagher D, Chu F et al. Effects of gender, body composition, and menopause on plasma concentrations of leptin. Journal of Clinical Endocrinology and Metabolism 199681 3424-3427.

43 Ostlund RE, Yang JW, Klein S \& Gingerich R. Relation between plasma leptin concentration and body fat, gender, diet, age, and metabolic covariates. Journal of Clinical Endocrinology and Metabolism 199681 3909-3913.

Received 18 November 1998

Accepted 8 March 1999 